Jurnal Tanah dan Sumberdaya Lahan Vol 7 No 2 : 299-304, 2020

e-ISSN:2549-9793, doi: 10.21776/ub.jts1.2020.007.2.14

\title{
PENGARUH PEMBERIAN SOLID (TANDAN KOSONG KELAPA SAWIT) DAN ARANG SEKAM PADI TERHADAP PRODUKSI TANAMAN TOMAT
}

\section{Eftect of Provision of Solid (Oil Palm Empty Fruit Bunch) and Rice Husk Charcoal on Tomato Plant Production}

\author{
Wizni Fadhillah ${ }^{1 *}$, Fitra Syawal Harahap ${ }^{2}$ \\ ${ }^{1}$ Program Studi Agroteknologi Fakultas Agroteknologi Universitas Muhammadiyah Sumatera Utara \\ 2 Program Studi Agroteknologi Fakultas Sains dan Teknologi Universitas Labuhan Batu Sumatera Utara \\ *Penulis korespondensi : wizniefadhillah@gmail.com
}

\begin{abstract}
This study aimed to determine the effect of various types of solid (oil palm empty fruit bunches) and rice husk charcoal on the production of tomato plant (Solanum lycopersicum $\mathrm{L}$ ). The treatments tested for this study consisted of two factors. The first factor was the provision of solid, i.e. S0 = without solid (control), $\mathrm{S} 1=0.50 \mathrm{~kg}$ solid polybag-1 ${ }^{-1} \mathrm{~S} 2=0.70 \mathrm{~kg}$ solid polybag- ${ }^{-1}$, and $\mathrm{S} 3: 1 \mathrm{~kg}$ solid polybag- ${ }^{-1}$. The second factor was the provision of rice husk charcoal, i.e. P0 $=$ without husk charcoal (control), P1 $=0.2 \mathrm{~kg}$ husk charcoal polybag-1 ${ }^{-1}$ and P2 $=0.4 \mathrm{~kg}$ husk charcoal polybag- ${ }^{-1}$. Each polybag contained $5 \mathrm{~kg}$ of air-dried soil. The results of this study indicated that the provision of solid and rice husk charcoal against tomato plant production had no significant effect on stem diamater, total number of fruits per plant, and total weight of fruits per plant. However, the treatment interaction of $1 \mathrm{~kg}$ solid polybag ${ }^{-1}$ and $0.2 \mathrm{~kg}$ husk charcoal polybag ${ }^{-1}$ increased stem diameter, total number of fruits per plant, and total weight of fruits per plant.
\end{abstract}

Keywords: charcoal, solid, rice husk, tomato plant

\section{Pendahuluan}

Tanaman tomat (Lycopersicum esculentum Mill) merupakan tanaman komoditas pertanian, mempunyai rasa yang unik, yakni perpaduan rasa manis dan asam, menjadikan tomat sebagai salah satu buah yang memiliki banyak penggemar (Gaswanto et al., 2009). Permintaan pasar terhadap komoditas tomat dari tahun ke tahun semakin meningkat. Luas areal budidaya tomat di Indonesia juga semakin bertambah. Sentra tanaman tomat pun bermunculan. Namun hingga saat ini masih banyak kendala yang dialami para petani tomat, mulai dari masalah penerapan teknik budidaya yang tepat, masalah hama dan penyakit, hingga masalah pemasaran hasil panen (Saragih, 2008). Salah satu upaya yang dilakukan untuk meningkatkan kualitas dan kuantitas tomat adalah dengan penambahan bahan organik dalam tanah.
Pemberian bahan organik melalui bokashi, selain dapat meningkatkan produktifitas tanah dan tanaman, penggunaan bahan organik merupakan salah satu komponen budidaya tanaman yang ramah lingkungan.

Dalam budidaya tanaman termasuk tomat, faktor lingkungan memegang peranan penting untuk mencapai pertumbuhan dan hasil yang maksimal. Hayati et al. (2012) menyatakan bahwa faktor lingkungan sangat berperan dalam proses pertumbuhan tanaman, media tumbuh adalah salah satu faktor lingkungan yang perlu dipertimbangkan. Selanjutnya juga dinyatakan bahwa media tanam yang baik biasanya digunakan campuran pasir, tanah, pupuk kandang. Penggunaan pasir sangat baik untuk perbaikan sifat fisik tanah terutama tanah liat. Osman (1996) menyatakan bahwa tanah dengan keadaan tekstur dan struktur yang baik sangat menunjang 
keberhasilan usaha pertanian, struktur tanah yang dikehendaki tanaman adalah struktur tanah yang gembur mempunyai ruang pori yang berisi air dan udara sehingga penyerapan unsur hara dapat berjalan optimal. Bua et al. (2017) menyatakan pupuk organik mempunyai pengaruh positif terhadap pertumbuhan dan produksi bawang bombai. Bobot basah, bobot kering, diameter umbi, dan produksi umbi bawang bombai lebih tinggi pada plot yang diberi perlakuan pupuk kandang. Pertumbuhan vegetatif bawang bombai yang tinggi pada perlakuan pupuk kandang menyebabkan intersepsi radiasi fotosintesis aktif lebih optimal, yang kemudian akumulasi asimilatnya yang tinggi akan disimpan di umbi. Sudarsono et al. (2013) juga menyatakan bahwa penambahan pupuk kandang sapi menghasilkan pertumbuhan dan serapan hara tanaman kedelai yang lebih baik dibandingkan tanpa pupuk.

Solid adalah limbah padat dari hasil samping proses pengolahan tandan buah segar (TBS) di pabrik kelapa sawit menjadi minyak mentah kelapa sawit atau Crude Palm Oil (CPO). Kandungan unsur hara dan bahan organik yang terdapat pada solid memungkinkan untukdapat digunakan sebagai penambah unsur hara pada tanaman, sehingga limbah pabrik kelapa sawit yang selama ini merugikan dapat dimanfaatkan dengan baik. (Anom dan Armaini, 2016). Sekam padi yang merupakan hasil sampingan dari sisa-sisa pembakaran juga dapat digunakan sebagai bahan media tanam (Rifai dan Subroto, 1982). Unsur hara yang terkandung dalam sekam padi relatif cepat tersedia bagi tanaman dan dapat meningkatkan $\mathrm{pH}$ tanah. Hasil penelitian Kolo dan Rahajo (2016) menunjukkan bahwa takaran arang sekam padi $0,5 \mathrm{~kg}$ memberikan hasil total panen per tanaman tertinggi yakni $646 \mathrm{~g}(1,9 \mathrm{t}$ $\left.\mathrm{ha}^{-1}\right)$. Frekuensi penyiraman tiga hari sekali dengan taraf air selama 90 hari adalah $120 \mathrm{~L}$ tanaman $^{-1}$ memberikan hasil total panen per tanaman tertinggi yakni 705,7g $\left(2,075 \mathrm{t} \mathrm{ha}^{-1}\right)$. Penambahan arang sekam pada media tumbuh akan menguntungkan, di antaranya mengefektifkan pemupukan karena selain memperbaiki sifat tanah (porositas, aerase), arang sekam juga berfungsi sebagai pengikat hara (ketika kelebihan hara) yang akan digunakan tanaman ketika kekurangan hara, kemudian hara tersebut dilepas secara perlahan sesuai kebutuhan tanaman atau slow release (Komarayati et al. 2003). Namun penggunaan arang sekam selama ini lebih banyak pada budidaya tanaman hias dan belum diketahui takarannya yang tepat. Oleh karena itu perlu diadakan penelitian tentang bagaimana penggunaan takaran arang sekam padi dan frekuensi penyiraman yang tepat sehingga dapat memberikan pertumbuhan dan hasil tomat yang paling optimal.

Pengaruh pupuk pada tanaman dipengaruhi selain oleh jenis, komposisi, dosis pupuk yang digunakan, juga oleh cara aplikasi dan waktu aplikasinya. Menurut Wasonowati (2011), ketersediaan hara yang cukup dan seimbang merupakan faktor penting yang dibutuhkan tanaman untuk menunjang laju pertumbuhan vegetatif yang baik. Pertumbuhan tinggi tanaman berkaitan dengan pertumbuhan batang, daun dan sistem perakaran tanaman. Menurut Akyas et al. (2004), diameter batang merupakan variabel pengamatan yang menunjukkan kekuatan tumbuh tanaman tomat karena merupakan pusat titik tumbuh tanaman. Pengaruh pupuk pada tanaman dipengaruhi selain oleh jenis, komposisi, dosis pupuk yang digunakan, juga oleh cara aplikasi dan waktu aplikasinya. Pertumbuhan tinggi tanaman berkaitan dengan pertumbuhan batang, daun dan sistem perakaran tanaman. Hasil penelitian Perwitasari et al. (2012) menunjukkan bahwa ketersediaan unsur hara bagi tanaman akan mempengaruhi kecepatan pertumbuhan dan perkem-bangan daun, batang dan akar tanaman tersebut. Besarnya jumlah dan komposisi nutrisi yang diberikan akan berpengaruh pada pertumbuhan tanaman.

Tujuan penelitian ini adalah untuk mempelajari pengaruh berbagai jenis solid (tandan kosong kelapa sawit) dan arang sekam padi terhadap produksi tanaman tomat.

\section{Bahan dan Metode}

Penelitian ini dilakukan di Kampung Sona dengan ketinggian 18 meter diatas permukaan laut Kabupaten Labuhanbatu pada bulan Desember 2019 sampai bulan Maret 2020. Penelitian akan dilakukan dengan rancangan kelompok faktorial. Faktor pertama ialah 
pemberian Solid yaitu $\mathrm{S}_{0}$ : tanpa solid (kontrol), $\mathrm{S}_{1}: 0,50 \mathrm{~kg}$ polybag-1 $\mathrm{S}_{2}: 0,70 \mathrm{~kg}$ polybag $^{-1} \mathrm{~S}_{3}: 1$ $\mathrm{kg}$ polybag-1. $^{-1}$ Faktor yang kedua ialah pemberian arang sekam padi $\mathrm{P}_{0}$ : tanpa arang sekam (kontrol), $\mathrm{P}_{1}: 0,2 \mathrm{~kg}$ polybag ${ }^{-1}, \mathrm{P}_{2}: 0,4$ $\mathrm{kg}$ polybag-1. Jumlah kombinasi perlakuan adalah 12 kombinasi. Selanjutnya data dianalisis dengan Analisis of Variance (ANOVA) untuk setiap parameter yang diukur dan diuji lanjutan bagi perlakuan yang nyata dengan menggunakan Uji Jarak Berganda Duncan (Duncan Multiple Range Test) dengan taraf 5\% (Gomez and Gomesz 1995).

Pengambilan tanah sebagai media tanam di ambil dari Kampung Sona, Kabupaten Labuhanbatu. Pengambilan contoh tanah dilakukan secara komposit dari beberapa titik pengambilan acak pada kedalaman $0-20 \mathrm{~cm}$ dari permukaann tanah, dan tanah dikering udarakan serta diayak dengan ayakan ukuran 10 mesh. Tanah yang telah dikering udarakan dan telah di ayak, setelah tanah dikering udarakan dan diayak dengan ayakan 10 mesh, tanah dimasukkan ke polybag setara $5 \mathrm{~kg}$ berat tanah kering oven kemudian tanah dicampur merata dengan solid dan arang sekam padi sesuai dengan dosis masing-masing, kemudian diinkubasi selama 2 minggu Setelah Benih tomat dikecambahkan pada media tanam selama 21 hari. Selama proses pengecambahan media disiram pagi dan sore hari sampai media menjadi lembab. Persiapan media tanam dilakukan penanaman benih sebanyak 3 biji polybag-1. Kemudian dilanjutkan dengan penjarangan tanaman yang berumur 2 minggu setelah tanam dengan meninggalkan satu tanaman yang pertumbuhannya baik. Pemanenan dilakukan pada masa akhir vegetatif tanaman yaitu setelah tanaman berumur \pm 7-8 minggu setelah tanam. Parameter yang diukur diamater batang $(\mathrm{cm})$, total jumlah buah per tanaman (butir), total bobot buah per tanaman (g)

\section{Hasil dan Pembahasan}

\section{Diamater batang}

Hasil analisis ragam terhadap data pemberian solid dan arang sekam padi menunjukkan bahwa pemberian solid dan arang sekam padi tidak berpengaruh nyata terhadap diamater batang tanaman tomat (Tabel 1). Meskipun tidak berbeda nyata antara perlakuan pemberian solid dan abu sekam padi dapat dilihat nilai rataan tertinggi dan terendah pada diamater batang tanaman tomat $(\mathrm{cm})$, rataan tertinggi pada $\mathrm{S}_{3} \mathrm{P}_{1}$ sebesar $3,66 \mathrm{~cm}$ dan terendah adalah pada $\mathrm{S}_{0} \mathrm{P}_{0}$ sebesar $3,10 \mathrm{~cm}$. Peningkatan diameter batang suatu tanaman juga dapat menggambarkan pertumbuhan dan perkembangan vegetatif tanaman. Tanaman yang memiliki diameter batang besar, menunjukkan bahwa asimilat yang ditranslokasikan ke bagian batang cukup banyak untuk penimbunan asimilat. Selain daun, batang juga memiliki klorofil sehingga dapat melakukan fotosintesis.

Tabel 1. Rataan diamater batang (cm).

\begin{tabular}{ccccc}
\hline Solid & \multicolumn{4}{c}{ Arang Sekam Padi } \\
\cline { 2 - 5 } & $\mathbf{P}_{\mathbf{0}}$ & $\mathbf{P}_{\mathbf{1}}$ & $\mathbf{P}_{\mathbf{2}}$ & Rataan \\
\hline $\mathrm{S}_{0}$ & 3,01 & 3,31 & 3,39 & 3,24 \\
$\mathrm{~S}_{1}$ & 3,42 & 3,45 & 3,46 & 3,44 \\
$\mathrm{~S}_{2}$ & 3,41 & 3,61 & 3,32 & 3,45 \\
$\mathrm{~S}_{3}$ & 3,22 & 3,66 & 3,51 & 3,46 \\
\hline Rataan & 3,27 & 3,51 & 3,42 & 3,40 \\
\hline
\end{tabular}

Proporsi tinggi tanaman dengan diameter batang dapat menjadikan tanaman tomat kokoh berdiri, sehingga mendukung pertumbuhan dan perkembangan tanaman tomat itu sendiri (Yusrianawati, 2011). Hal ini juga didukung oleh Murbandono (2008), menyatakan bahan organik mampu mengikat unsur hara dan mempertahankan unsur hara tersebut agar tidak tercuci sehingga akan membuat keadaan unsur hara yang tetap tersedia dalam tanah. Pengaturan jarak tanam pada dasarnya adalah memberikan 
kemungkinan tanaman untuk tumbuh dengan baik tanpa mengalami banyak persaingan dalam hal mengambil air, unsur hara, dan cahaya matahari.

\section{Jumlah buah}

Hasil analisis ragam terhadap data pemberian solid dan arang sekam padi tersebut menunjukkan bahwa pemberian bahan pemberian solid dan arang sekam padi tidak berpengaruh nyata terhadap jumlah buah tanaman tomat (Tabel 2). Meskipun tidak berbeda nyata antara perlakuan pemberian solid dan abu sekam padi dapat dilihat nilai rataan tertinggi dan terendah pada jumlah buah tanaman tomat $(\mathrm{cm})$, rataan tertinggi pada $\mathrm{S}_{3} \mathrm{P}_{1}$ sebesar 7,80 butir dan terendah adalah pada $\mathrm{S}_{0} \mathrm{P}_{0}$ sebesar 1,57 butir. Hal ini karena pada jarak tanam yang lebih rapat jumlah populasi tanaman lebih banyak sehingga akan menghasilkan buah yang lebih banyak. Terjadi persaingan untuk mendapatkan unsur hara pada tanaman tomat namun telah tercukupi dengan adanya pemberian arang sekam padi sehingga tidak berpengaruh terhadap jumlah buahnya. Tersedianya unsur hara makro dan mikro yang ada dalam pupuk organik dimanfaatkan oleh tanaman untuk pertumbuhan generatif yang mempengaruhi jumlah produksi. Pada pemberian solid dan arang sekam padi menghasilkan jumlah buah per plot lebih sedikit dibanding dengan jarak tanam yang rapat. hal ini dipengaruhi oleh kesetimbangan hara yang terjadi dalam tanah. Kesetimbangan hara yang baik dalam tanah dapat memengaruhi produksi (Caspersen $e t$ al., 2016; Tautges et al., 2016) dengan jumlah populasi tanaman lebih sedikit.

Pada tanaman tomat pemberian solid dan abu sekam padi menghasilkan jumlah buah per plot yang lebih banyak. Hal ini terjadi karena jumlah populasi tanaman yang lebih banyak, sehingga akan menghasilkan jumlah buah per plot yang lebih banyak. Kesetimbangan hara yang harmonis dalam tanah sangat memengaruhi penyerapan yang baik, sehingga diharapkan dapat meningkatkan produksi tanaman (Pincus et al., 2016). Oleh karfena itu, pemberian solid dan arang sekam padi sebaiknya dilakukan bersamaan, karena pupuk hayati kaya akan mikrob dapat membantu perombakan bahan organik dari kompos. Hal ini diharapkan dapat mengoptimalkan perubahan senyawa organik menjadi bentuk ion yang dapat tersedia dan terserap oleh tanaman, seiring dengan adanya peningkatan produksi (Wang et al., 2015).

Tabel 2. Total jumlah buah per tanaman (g).

\begin{tabular}{ccccc}
\hline Solid & \multicolumn{4}{c}{ Arang Sekam Padi } \\
\cline { 2 - 5 } & $\mathbf{P}_{\mathbf{0}}$ & $\mathbf{P}_{\mathbf{1}}$ & $\mathbf{P}_{\mathbf{2}}$ & Rataan \\
\hline $\mathrm{S}_{0}$ & 1,57 & 4,10 & 2,90 & 2,86 \\
$\mathrm{~S}_{1}$ & 5,90 & 3,77 & 4,87 & 5,55 \\
$\mathrm{~S}_{2}$ & 4,77 & 6,53 & 5,33 & 4,42 \\
$\mathrm{~S}_{3}$ & 5,67 & 7,80 & 4,57 & 4,67 \\
\hline Rataan & 4,48 & 5,55 & 4,42 & 4,36 \\
\hline
\end{tabular}

\section{Bobot buah}

Hasil analisis sidik ragam terhadap data pemberian solid dan arang sekam padi tersebut menunjukkan bahwa pemberian bahan pemberian solid dan arang sekam padi tidak berpengaruh nyata terhadap bobot buah per tanaman tomatn (Tabel 3). Meskipun tidak berbeda nyata antara perlakuan pemberian solid dan abu sekam padi dapat dilihat nilai rataan tertinggi dan terendah pada bobot buah tanaman tomat, rataan tertinggi pada $\mathrm{S}_{3} \mathrm{P}_{1}$ sebesar 271,10 g dan terendah adalah pada $\mathrm{S}_{0} \mathrm{P}_{0}$ sebesar 40,57 g. Fotosintat yang dihasilkan oleh tanaman selain digunakan untuk pertumbuhan dan perkembangan juga disimpan oleh tanaman sebagai cadangan makanan. Fotosintat yang terdapat dalam daun diangkut keseluruh tubuh tanaman, yaitu bagian meristem di titik tumbuh dan ke buah-buah yang sedang dalam perkembangan. Jika fotosintesis yang dilakukan oleh tanaman dapat berlangsung dengan 
optimal maka fotosintat yang dihasilkan akan optimal juga, yang akhirnya akan berpengaruh pada ukuran dan berat buah. Menurut Soleh (2009), bahan organik dalam tanah bagi tanaman juga dapat memperbaiki pertumbuhan generatif terutama fase pembentukan bunga dan proses pembuahan. Apabila pertumbuhan vegetatif baik, fotosintat yang dihasilkan semakin banyak, hal ini menyebabkan kemampuan tanaman untuk membentuk organ-organ generatif semakin meningkat. Dengan pengaturan jarak tanam yang baik, maka pemanfaatan ruang tumbuh yang ada bagi pertumbuhan tanaman dan kapasitas penyangga terhadap peristiwa yang merugikan dapat diefisienkan. Hamim (2010), tanaman tomat perlu ditanam dengan jarak tanam yang ideal sehingga dapat meningkatkan hasil produksi. Pada jarak yang rapat yaitu kepadatan populasi tinggi, maka terjadi kompetisi yang berat antar tanaman yang berakibat terhambatnya pertumbuhan dan penurunan hasil tanaman. Semakin rapat jarak tanam maka persaingan diantara tanaman untuk mendapatkan cahaya juga semakin terbatas, sehingga bila terjadi pengurangan cahaya pada fase pembentukan buah maka akan menghasilkan buah yang relatif kecil.

Tabel 3. Total bobot buah per tanaman (g).

\begin{tabular}{ccccc}
\hline Solid & \multicolumn{4}{c}{ Arang Sekam Padi } \\
\cline { 2 - 5 } & $\mathbf{P}_{\mathbf{0}}$ & $\mathbf{P}_{\mathbf{1}}$ & $\mathbf{P}_{\mathbf{2}}$ & Rataan \\
\hline $\mathrm{S}_{0}$ & 40,57 & 120 & 87,70 & 82,79 \\
$\mathrm{~S}_{1}$ & 187,90 & 120 & 262,23 & 190,04 \\
$\mathrm{~S}_{2}$ & 136,53 & 226,67 & 173,33 & 178,84 \\
$\mathrm{~S}_{3}$ & 166,57 & 271,10 & 151,13 & 196,27 \\
\hline Rataan & 132,89 & 184,44 & 168,62 & 161,99 \\
\hline
\end{tabular}

\section{Kesimpulan}

Hasil penelitian ini menunjukkan bahwa pemberian pemberian solid dan arang sekam padi terhadap produksi tanaman tomat (Solanum bycopersicum L) tidak berpengaruh nyata terhadap diamater batang, jumlah buah per tanaman, bobot buah per tanaman, tetapi perlakuan interaksi solid $1 \mathrm{~kg}^{\text {polybag- }}{ }^{-1}$ dan arang sekam padi $0,2 \mathrm{~kg}$ polybag $^{-1}$ dapat meningktatkan diamater batang, jumlah buah per tanaman, dan bobot buah per tanaman.

\section{Daftar Pustaka}

Akyas, A.M., Widayat, D. and Nursuhud. 2004. Research and development in hydroponics technology at the Laboratory of Horticulture Padjadjaran University (a case with tomato cultivar Recento). The 5th International Symposium-Cum-Workshop in Southeast Asia. The Role of German Alumni In Rural/ Regional Development And Entrepreneurship, 23- 27 August 2004, Phnom Penh - Cambodia.

Anom, E. dan Armaini, A. 2016. Aplikasi Solid pada Medium Bibit Kelapa Sawit (Elaeis guineensis Jacq.) di Main Nursery. Disertasi, Universitas Riau.

Bua, B., Owiny, R. and Akasairi, O. 2017. Response of onion to different organic amendments in central Uganda. Journal of Agriculture Science and Technology 7:79-85.

Caspersen, S., Svensson. B., Hakansson, T., Winter, C., Khalil, S. and Asp, H. 2016. Blueberry-Soil interactions from an organic perspective. Scientia Horticulturae 208: 78-91.

Gaswanto, R., Gunaeni, N. dan Duriat, A.S. 2009 Seleksi tanaman tomat berdasarkan ketahanan pasif dan aktif terhadap CMV. Jurnal Hortikultura 19(4):377-385.

Gomez, K .A. dan Gomez, A.A. 1995. Prosedur Statistik untuk Penelitian Pertanian. Edisi ke 2. Jakarta: UI Press.

Hamim. T. 2010. Kajian jarak tanaman pada tumpangsari tomat (Lycopersicum esculentum Mill.) dan bawang prei (Allium fistulosum). Jurnal Ilmu Pertanian 11(1): 32-40.

Hayati, E., Sabaruddin dan Rahmawati. 2012. Pengaruh jumlah mata tunas dan komposisi media tanam terhadap pertumbuhan setek tanaman jarak pagar (Jatropha curcas L.) Jurnal Agrista 16(3): 129-134.

Kolo, A. dan Raharjo, K.T.P. 2016. Pengaruh pemberian arang sekam padi dan frekuensi 
Jurnal Tanah dan Sumberdaya Lahan Vol 7 No 2 : 299-304, 2020

e-ISSN:2549-9793, doi: 10.21776/ub.jts1.2020.007.2.14

penyiraman terhadap pertumbuhan dan hasil tanaman tomat (Lycopercicom esculentum Mill). Savana Cendana 1(03): 102-104.

Komarayati, S. dan Indrawati, I. 2003. Isolasi dan identifikasi mikroorganisme dalam arang kompos. Jurnal Penelitian Hasil Hutan 21(3): 251-258.

Murbandono, L. 2008. Membuat Bokashi. Penebar Swadaya, Jakarta.

Osman, F. 1996. Memupuk Tanaman Padi dan Palawija. Penebar Swadaya, Jakarta.

Perwitasari, B., Tripatmasari, M. dan Wasonowati, C. 2012. Pengaruh media tanam dan nutrisi terhadap pertumbuhan dan hasil tanaman pakchoi (Brassica juncea L.) dengan sistem hidroponik. Agrovigor 5(1): 14-25.

Pincus, L., Margenot, A., Six, J. and Scow, K. 2016. On-farm trial assessing combined organic and mineral fertilizer amendments on vegetable yields in central Uganda. Agriculture, Ecosystems and Environment 225: 62-71.

Rifai, B. dan Soebroto, S.R. 1982. Ilmu Memupuk II. CV. Yasa Guna, Jakarta

Saragih, W.C. 2008. Respon Pertumbuhan dan Produksi Tomat Terhadap Pemberian Pupuk Phospat dan Bahan Organik. Skripsi. Universitas Sumatera Utara.
Soleh. A. 2009. Pemanfaatan Pupuk Kandang Ayam Untuk Pertumbuhan dan Produksi Tanaman Hortikultura. Transindo, Jakarta.

Sudarsono, W.A., Melati, M. dan Aziz, S.A. 2013. Pertumbuhan, serapan hara dan hasil kedelai organik melalui aplikasi pupuk kandang. Jurnal Agronomi Indonesia 41: 202-208.

Tautges, N.E., Sullivan, T.S., Reardon, C.L. and Burke, I.C. 2016. Soil microbial diversity and activity linked to crop yield and quality in a dryland organic wheat production system. Applied Soil Ecology 108: 258-268.

Wang, S., Tan, Y., Fan, H., Ruan, H. and Zheng, A. 2015. Responses of soil microarthropods to inorganic and organic fertilizers in a popular plantation in a coastal area of eastern China. Applied Soil Ecology 89: 69-75.

Wasonowati, C. 2011. Meningkatkan pertumbuhan tanaman tomat (Lycopersicon esculentum) dengan sistem budidaya hidroponik. Agrovigor 4(1): 21 27.

Yusrianawati. 2011. Pengaruh Pemberian Beberapa Macam Pupuk Daun terhadap Pertumbuhan dan Hasil Tanaman Tomat (Lycopersicum esculentum Mill.). Prosiding Seminar. Jurusan Budidaya Pertanian Universitas Gadjahmada, Yogyakarta. 